\title{
Borggård-1-Kernen på Bornholm - ny viden om Nedre Kambrium på vej
}

\section{Af Geolog Johan Svendsen, Altinex Oil} Denmark

Henover foråret og sommeren blev der på det sydøstlige Bornholm udført en boring, der vil få afgørende indflydelse på vores forståelse af den nedre del af den danske sedimentære lagserie.

Ved Borggård nær Pedersker på Bornholm udførte Arne Thorshøj Nielsen (Geologisk Museum) og Kurt Klitten (GEUS) en lidt over 300 meter dybkernet boring som led $\mathrm{i}$ et projekt finansieret af Geocenter København. Boringens primære formål var at vurdere hydrogeologiske forhold i de "Grønne Skifre" (Broens Odde Mb i Læså Fm.) og den øvre del af Balka Sandstenen (Hardeberga Fm). Boringen blev derfor placeret således, at Læså Formationen ville blive truffet under en tynd kile af Alunskifer Fm.

\section{Boringen}

Da alt gik, som det skulle, kom man på lidt over 100 m's dybde ned i Balka Sandstenen, der i den øvre del er den klassiske og velkendte kvartsitiske sandsten, der kendes fra adskillige stenbrud på Bornholm, mens den i den nedre del indeholder ret tykke indslag af muddersten.

Balka Sandstenen og den forholdsvis dårligt kendte rød-stribede "Gingham sandsten", som danner en overgang mellem Balka og Nexø sandstenene, viste sig imidlertid at være en hel del tykkere end forventet, hvilket bogstaveligt talt var en streg i regningen. Men med økonomisk tilskud fra GEUS, fonde og olieselskaber lykkedes det alligevel til sidst at få boringen hele vejen igennem både Balka Sandstenen og Nexø Sandstenen samt seks meter ned i grundfjeldet.

Den borede kerne er af meget høj kvalitet, med en bevaringsgrad på nær $100 \%$ - en cadeau til Faxe Kalks boreteam, som stod for den praktiske del af borearbejdet.

“Kan denne kerne så bruges til noget?” - Hertil må svaret være et rungende "Ja!". Borggård-1-kernen giver en helt unik mulighed for at forstå udviklingen af Nedre Kambrium på Bornholm. Og selvom dette stratigrafiske interval ikke nødvendigvis er mere spændende end andre intervaller, så er

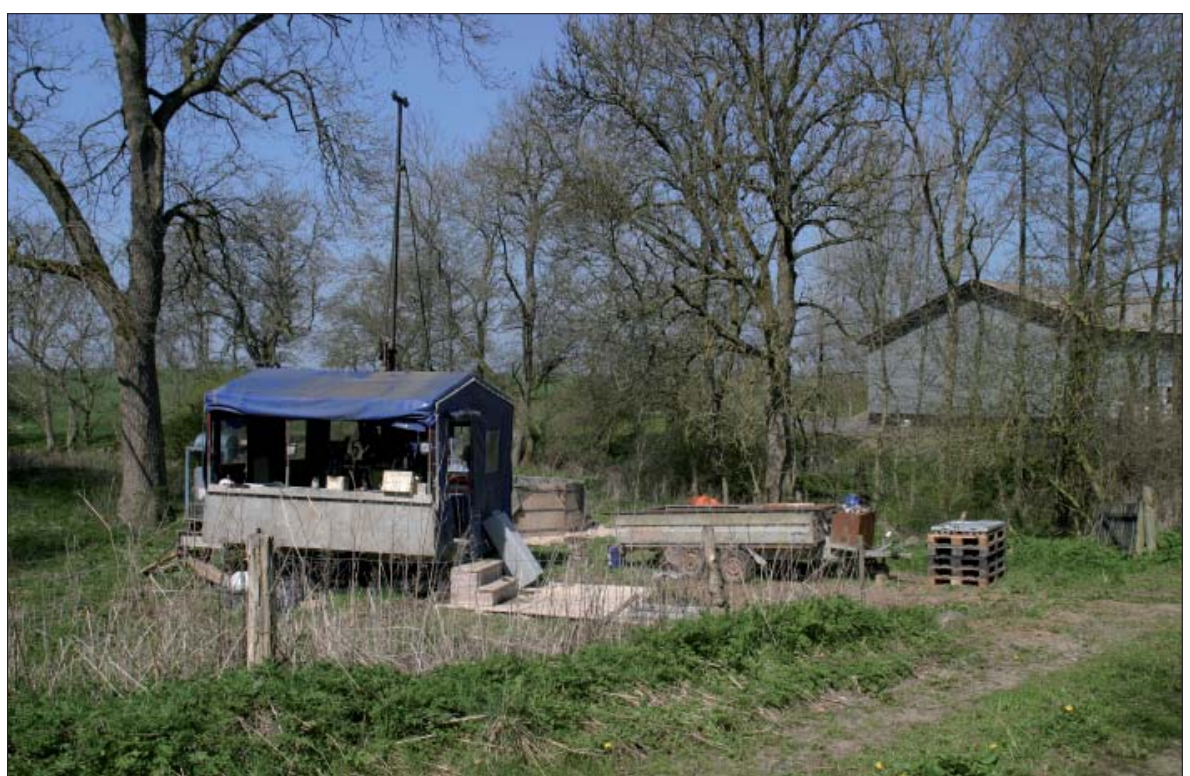

Ovenfor ses boringens placering (Foto: Arne Thorshøj Nielsen). Nedenfor til højre ses dele af borekernen fra Nedre Kambrium. (Foto: Forfatteren)

der vel mange geologer, der tænker tilbage til deres studiestart, når de hører ord som Nexø Sandsten og Balka Sandsten. Kernen er derfor særdeles vigtig for forskningen $\mathrm{i}$ Nedre Kambrium, men også for alle geologi-studerende og andre geologi-interesserede udgør kernen en vigtig brik i det store geologiske puslespil. Hertil kommer, at Balka og "Gingham" sandstenene er meget vigtige for vandindvindingen på Bornholm og den overraskende nyhed, at det kvartsitdominerede grundvandsmagasin er ca. dobbelt så tykt som oprindeligt antaget, giver selvfølgelig et nyt perspektiv for vandindvindingen.

Borggård-1 kernen er nu kommet til København, hvor den i øjeblikket underkastes de første analyser og beskrivelser. Herefter følger mere detaljeret arbejde, som vil strække sig nogle år ud i fremtiden.

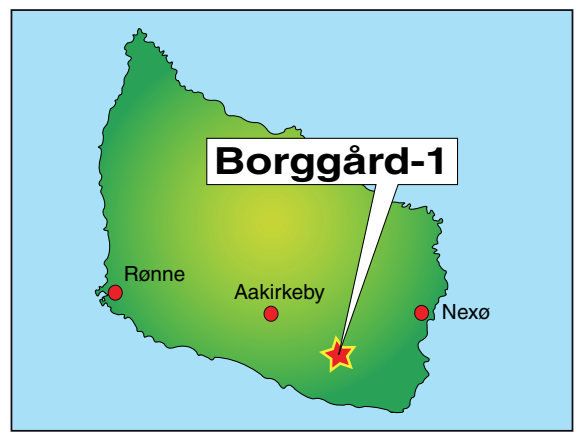

Borggård-1. (Grafik: UVH efter forfatteren)

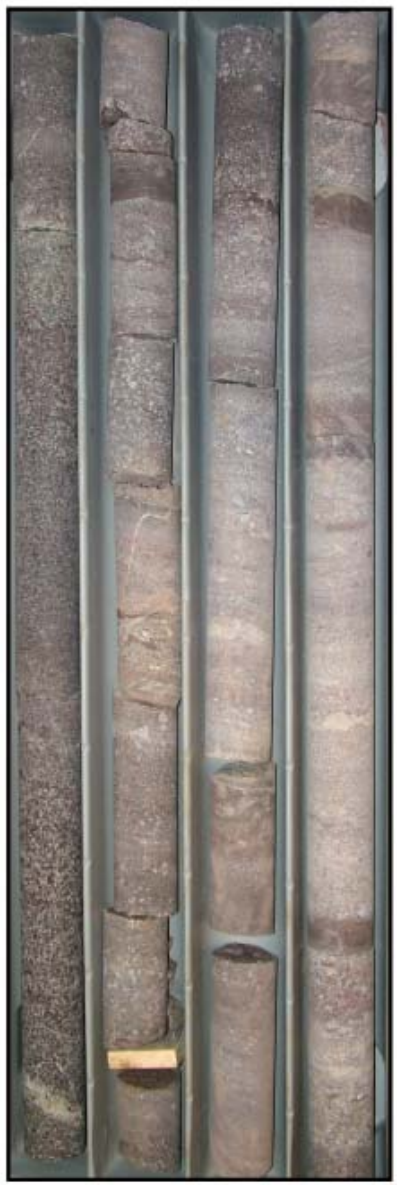

